\title{
MODEL KERUKUNAN SOSIAL PADA MASYARAKAT MULTIKULTURAL CINA BENTENG (KAJIAN HISTORIS DAN SOSIOLOGIS)
}

\author{
Muhamad Arif \\ Fakultas llmu Tarbiyah dan Keguruan (FITK) UIN Syarif Hidayatullah Jakarta \\ Email: arifia555@yahoo.co.id
}

\begin{abstract}
This study was conducted to gain an overview of the historical and sociological perspective of the model of social harmony in a multicultural society of Cina Benteng, Tangerang. It used descriptive qualitative research method using an inductive approach in conducting the analysis. Data collection techniques mainly emphasize on library research techniques, interview, observation, and documentation. There are two important conclusions generated in this study. The first, models of social cohesion in a multicultural society of Cina Benteng has historically formed since their arrival in the watershed Cisedane. Historical process has made Cina Benteng society has a unique blend, namely their persistence in holding the customs of their ancestors already bundreds of years old, as well as their flexibility to enable them to carry out the process of amalgamation, assimilation, and acculturation with the local community and culture as well. Second, in a sociological perspective, the model of social barmony in Cina Benteng society is not just happening in the field of art, but also occurs in settlement patterns, language of communication, traditional wedding procession, traditional clothes, gambang kromong music, and cokek dance.
\end{abstract}

Keywords: social cohesion, amalgamation, assimilation, acculturation

\begin{abstract}
Abstrak
Penelitian ini dilakukan untuk memperoleh gambaran tentang perspektif historis dan sosiologis dari model harmoni sosial dalam masyarakat multikultural Cina Benteng, Tangerang. Studi ini menggunakan metode penelitian deskriptif kualitatif dengan memakai pendekatan induktif dalam melakukan analisis. Teknik pengumpulan data terutama menekankan pada teknik studi pustaka, wawancara, observasi, dan dokumentasi. Ada dua kesimpulan penting yang dihasilkan dalam penelitian ini. Yang pertama, model kohesi sosial dalam masyarakat multikultural cina Benteng secara historis terbentuk sejak kedatangan mereka di daerah aliran sungai Cisedane. Proses sejarah telah membuat masyarakat Cina Benteng memiliki perpaduan unik, yaitu ketekunan mereka dalam memegang adat istiadat nenek moyang mereka yang sudah ratusan tahun, serta fleksibilitas mereka untuk memungkinkan mereka untuk melaksanakan proses amalgamasi, asimilasi, dan akulturasi dengan masyarakat setempat dan budaya juga. Kedua, dalam perspektif sosiologis, model harmoni sosial dalam masyarakat Cina Benteng tidak hanya terjadi di bidang seni, tetapi juga terjadi di pola pemukiman, bahasa komunikasi, prosesi pernikahan tradisional, pakaian tradisional, gambang kromong musik, dan cokek tari.
\end{abstract}

Kata kunci: kohesi sosial, amalgamasi, asimilasi, akulturasi

\section{A. Pendahuluan}

\section{Latar Belakang}

Keanekaragaman suku bangsa dan budaya Indonesia merupakan realitas historis dan sekaligus realitas sosio-kultural. Terlalu banyak kajian yang semakin mematenkan betapa bangsa Indonesia memiliki berbagai elemen pendukung multikultural, dimana terdapat sekitar tigaratusan kelompok etnis dengan budaya, adat-istiadat, dan bahasa pengantar komunikasi berbeda-beda. Pada pertengahan tahun 1980-an saja terdapat sekitar 14 etnis besar yang masing-masing memiliki populasi lebih dari satu juta orang. ${ }^{1}$ Secara teoritis, Watson Kamanto Sunarto, "Multicultural Education in Schools: Challenges
in Its Implementation" dalam Multicultural Education in Indonesia and
Southeast Asia: Stepping into the Unfamilliar (Kamanto Sunarto, Russell Hiang-
Khung, Ahmad Fedyani Saifuddin, eds, 2004), Jurnal Antropologi Indonesia in 
memaknai masyarakat multikultural sebagai masyarakat yang di dalamnya berkembang banyak kebudayaan. ${ }^{2}$ Sementara Suryadinata mengartikan masyarakat multikultural sebagai masyarakat yang tersusun dari berbagai macam bentuk kehidupan dan orientasi nilai. ${ }^{3}$

Masyarakat multikultural adalah masyarakat yang kompleks. Kompleksitas itu membawa banyak konsekuensi, baik berupa peluang maupun tantangan, dalam pembangunan. Oleh karena itu, kajian terhadap masyarakat multikultural menjadi penting, terutama bagi bangsa Indonesia yang tengah bersemangat untuk menggerakkan potensi pembangunan. Beberapa kalangan beranggapan bahwa keragaman dan keberagamaan tersebut merupakan akar berbagai konflik sosial yang meletus di berbagai kawasan. Ini semakin menegaskan bahwa pembentukan karakter (character building) menjadi penting agar tercapai "nation building" dalam masyarakat dengan komposisi multikultural.

Fakta-fakta sosiologis berupa konflikkonflik sosial yang terjadi dari masyarakat di berbagai daerah tak kurang merupakan hambatan bagi terbentuknya integrasi sosial dalam sebuah masyarakat besar yang bernama masyarakat Indonesia. Dalam konteks ini, menjadi penting untuk menggali model-model kerukunan sosial pada masyarakat multikultural yang justru telah melembaga dalam kehidupan masyarakat Indonesia secara nyata. Dalam hal ini, masyarakat Cina Benteng Tangerang, baik secarra historis maupun secara sosiologis, bisa dianggap sebagai salah satu model yang menarik untuk diteliti. Seperti yang secara awam diketahui bahwa masyarakat Cina Benteng memiliki keunikan tersendiri dibandingkan dengan masyarakat Banten atau bahkan masyarakat Indonesia pada umumnya. Wilayah Banten, di mana Tangerang menjadi bagiannya, telah menjadi melting pot yang mempertemukan berbagai macam etnis, agama, dan budaya. Dengan demikian, masyarakat Cina Benteng, Tangerang, dengan komposisi kultur yang majemuk, merupakan sampel yang representatif.

\footnotetext{
Collaboration with TIFA Foundation, Departement of Antropology, Faculty of Social and Political Sciences, Univercity of Indonesia, 2004.

2 C.W. Watson, Multiculturalism Concepts in the Social Studies, Open University Press, 2000, h.1.

3 Suryadinata, Penduduk Indonesia, Etnis dan Agama dalam Era Perubahan Politik, Jakarta: LP3ES, 2004, h.ix.
}

Secara implisit istilah "multikultural" itu sendiri adalah konsep kultur yang merujuk pada kesamaan bahasa, sejarah, keyakinan agama, asal wilayah geografis, ras, kebangsaan, dan etnis. ${ }^{4}$

Bicara tentang model kerukunan antarumat beragama dalam perspektif historis dan sosiologis pada masyarakat Cina Benteng Tangerang tidak dapat dilepaskan dari pengaruh budaya yang kompleks dalam kehidupan masyarakatnya. Masyarakat multikultural yang berada di wilayah Cina Benteng Tangerang memiliki warna yang sangat beragam dan didominasi oleh etnis Sunda, Betawi, Jawa, dan Cina. Pengaruh kehidupan multikultural sangat terasa pada komunitas publik dalam kaitannya dengan tujuan penelitian ini hal itu antara lain tampak dalam praktik kerukunan sosial yang telah terbangun dalam kehidupan masyarakat Cina Benteng Tangerang.

Penelitian ini akan difokuskan pada model kerukunan sosial pada masyarakat Cina Benteng Tangerang dalam perspektif historis dan sosiologis. Kajian historis dimaksudkan untuk mencari hubungan-hubungan kausalitas terbentuknya masyarakat Cina Benteng yang secara kronologis telah terjadi ratusan tahun yang lalu. Sementara kajian sosiologis dimaksudkan untuk memotret realitas empirik tentang model-model kerukunan sosial yang terbangun dalam kehidupan masyarakat Cina Benteng Tangerang.

\section{Rumusan Masalah}

Pertanyaan mendasarnya adalah: bagaimanakah perspektif historis dan sosiologis model kerukunan sosial pada masyarakat multikultural Cina Benteng Tangerang? Guna mempeorleh jawaban secara lebih detail perlu dimunculkan pertanyaan dasar (basic questions) sebagai berikut:

a. Bagaimanakah perspektif historis tentang keberadaan masyarakat multikultural Cina Benteng di Kabupaten Tangerang?

b. Bagaimanakah perspektif sosiologis dari model kerukunan sosial pada masyarakat multikultural Cina Benteng Tangerang?

4 C.W. Watson, Multiculturalism Concepts in the Social Studies, Open University Press, 2000, h.1. 


\section{Tujuan Penelitian}

Berdasarkan rumusan masalah di atas, maka tujuan utama dari penelitian ini adalah untuk memperoleh gambaran tentang perspektif historis dan sosiologis model kerukunan sosial pada masyarakat multikultural Cina Benteng Tangerang. Tujuan utama penelitian ini ditelusuri melalui pencapaian tujuan antara yang substantif sifatnya, yakni:

a. Untuk memperoleh gambaran tentang perspektif historis tentang keberadaan masyarakat multikultural Cina Benteng di Kabupaten Tangerang

b. Untuk memperoleh gambaran tentang perspektif sosiologis dari model kerukunan sosial pada masyarakat multikultural Cina Benteng Tangerang.

\section{Landasan Teori tentang Model Kerukunan Sosial pada Masyarakat Multikultural}

\section{a. Model Kerukunan Sosial}

Konsep model adalah suatu kerangka konseptual yang bersifat prosedural berupa sebuah pola atau rancangan yang dapat digunakan sebagai acuan dalam pengembangan program kerukunan sosial sebagai acuan setiap daerah untuk mengembangkan model.

Mengutip pernyataan Snelbecker model adalah perwujudan suatu teori atau wakil dari proses dan variabel yang mencakup dalam teori, ${ }^{5}$ sedangkan Horton seperti yang dikutip oleh Suriasumantri mengemukakan bahwa model bersifat menjelaskan hubungan berbagai komponen, aksi dan reaksi, serta sebab akibat. Lebih jelas lagi dinyatakan bahwa model biasanya digunakan untuk hal-hal yang bersifat menggambarkan sesuatu, menjelaskan suatu proses, mengkaji atau menganalisis sesuatu sistem, menggambarkan suatu kejadian, dan bersifat memprediksikan suatu keputusan yang akan diambil. ${ }^{6}$ Sejalan dengan pernyataan tersebut, Briggs dalam Gafur berpendapat bahwa model adalah seperangkat prosedur yang berurutan untuk mewujudkan suatu proses kerja.

Selanjutnya Snelbecker menyatakan bahwa

5 Glen Snelbecker, Learning Theory Instructional Theory, and Psycho-educational Design. USA: McGrau-Hill, Inc, 1984, h.32.

6 J.S. Suriasumantri, Berfikir Sistem:Konsep, Penerapan Teknologi dan Strategi Implementasi, Jakarta: FPS IKIP Jakarta, 1996, h.23. hampir semua cara pengembangan pembelajarn dinyatakan dalam bentuk model dengan alasan: (a) agar mudah dikomunikasikan kepada para calon pemakai, (b) dapat memperlihatkan tugas-tugas utama yang harus dikerjakan dan arena itu berguna sekali untuk keperluan pengelolaan, dan (c) memperlihatkan struktur semacam matriks di mana tujuan belajar dan strategi belajar dapat diperbandingkan dan disesuaikan. ${ }^{7}$ Jadi, yang dimaksud dengan model adalah suatu kerangka konseptual yang bersifat prosedural berupa sebua pola atau rancangan yang dapat digunakan sebagai acuan dalam pengembangan program kegiatan dalam rangka mempertahankan kerukunan sosial dalam masyarakat. Pengembangan model kerukunan sosial dalam perspektif agama adalah perwujudan dari teori multikulturalisme, teori interaksi sosial, akulturasi dan amalgamansi.

Kerukunan itu sendiri merupakan istilah yang sarat dengan makna "baik" dan "damai". Kerukunan berkonotasi sebagai kehidupan bersama dalam masyarakat dengan "kesatuan hati" dan "bersepakat" untuk tidak menciptakan perselisihan dan pertengkaran. Bila pemaknaan tersebut dijadikan pegangan, maka "kerukunan" adalah sesuatu yang ideal dan didambakan oleh masyarakat manusia. Kerukunan secara luas bermakna adanya suasana persaudaraan dan kebersamaan antar semua orang walaupun mereka berbeda secara suku, agama, ras, dan golongan.

Selain bermakna sebagai kemampuan dan kemauan untuk hidup berdampingan dan bersama dengan damai serta tenteram, kerukunan juga bermakna sebagai proses untuk menjadi rukun karena sebelumnya ada ketidakrukunan. Untuk mencapai kerukunan seperti itu, tentu diperlukan adanya proses dialog, saling terbuka, saling menerima, saling menghargai, serta saling menanamkan rasa cinta-kasih.

\section{b. Konsep Multikulturalisme}

Parsudi Suparlan menjelaskan bahwa akar kata multikulturalisme adalah kebudayaan, yaitu kebudayaan yang dilihat dari fungsinya sebagai pedoman bagi kehidupan manusia. Dengan demikian, konsep multikulturalisme tidak dapat

\footnotetext{
Glen Snelbecker, Learning Theory Instructional Theory, and Psycho-educational Design. USA: McGrau-Hill, Inc, 1984, h. 24.
} 
disamakan dengan konsep keanekaragaman suku bangsa dan kebudayaannya mengingat penekanan multikulturalisme terletak pada kesederajatan aneka ragam kebudayaan lengkap dengan berbagai suku bangsa pendukungnya dalam kehidupan berbangsa dan bernegara. ${ }^{8}$

Menurut Karim, gagasan multikulturalisme menekankanbahwakeragaman sosialmerupakan suatu kondisi yang tidak. Oleh karena itu, membangun semangat multikulturalisme berarti membangun kesetaraan dalam keragaman (equality in difference). Hubungan timbal balik dalam masyarakat multikultural merupakan suatu hal yang substansial. Agar hubungan timbal balik dapat berlangsung secara harmonis diperlukan tiga kompetensi normatif, yaitu kompetensi kebudayaan, kemasyarakatan, dan kepribadian. ${ }^{?}$

Multikulturalisme bukan sekedar mengakui yang berbeda tetapi lebih merupakan penempatan perbedaan secara simetris (symetrical differentiated citizenship), yakni dengan mengakui adanya pluralitas identitas dalam masyarakat. Melalui pengakuan terhadap pluralitas identitas maka masyarakat tidak lagi terjebak pada isuisu primordial dan/atau isu-isu sekterian yang bisa mengancam harmoni dalam kehidupan bersama. ${ }^{10}$

Sebagaimana yang dikutip dari Fay, Jary dan Jary, Watson, dan Reed, Parsudi Suparlan menguraikan bahwa multikulturalisme merupakan acuan utama bagi terwujudnya masyarakat multikultural. ${ }^{11}$ Sebagai sebuah ideologi, multikulturalisme mengakui dan mengagungkan perbedaan dalam kesederajatan. Dalam hal ini, masyarakat mempunyai sebuah kebudayaan yang berlaku umum yang coraknya seperti sebuah mosaik. Mosaik kebudayaan tersebut mencakup semua kebudayaan dari masyarakat-masyarakat yang lebih kecil untuk kemudian mewujudkan masyarakat yang lebih besar. Dengan demikian, multikulturalisme

\footnotetext{
8 Parsudi Suparlan, Menuju Masyarakat Indonesia Yang Multikultural, Makalah, Disajikan pada Simposium Internasional Jurnal Antropologi Indonesia ke-3, Membangun Kembali "Indonesia yang Bhinneka Tunggal Ika", Menuju Masyarakat Multikultural, Universitas Udayana, Denpasar, Bali, 16-19 Juli 2002.

9 Abdul Gafar Karim, Multikulturalisme. Yogyakarta: Bahan Ajar Program Pascasarjana Universitas Gajah Mada, 2010.

10 Syamsuddin Haris, Paradigma Baru Otonomi Daerah. Jakarta: Pusat Penelitian Politik Lembaga Ilmu Pengetahuan Indonesia (P2P LIPI), 2001.

11 Parsudi Suparlan, Menuju Masyarakat Indonesia Yang Multikultural, Makalah, Disajikan pada Simposium Internasional Jurnal Antropologi Indonesia ke-3, Membangun Kembali "Indonesia yang Bhinneka Tunggal Ika", Menuju Masyarakat Multikultural, Universitas Udayana, Denpasar, Bali, 16-19 Juli 2002.
}

diperlukan dalam bentuk tata kehidupan masyarakat yang damai dan harmonis meskipun terdiri dari beraneka ragam latar belakang kebudayan.

Scott Lash, et al., dalam buku Recognition And Difference: Politics, Identity Multiculture, menjelaskan bahwa multikulturalisme berarti "keberagamaan"budaya. ${ }^{12}$ Terdapat tiga istilah yang sering digunakan untuk menggambarkan masyarakat yang beragam, baik secara agama, ras, bahasa, dan budaya, yaitu pluralitas (plurality), keragamaan (diversity), dan multikultural (multikultural). Meskipun ketiganya sama-sama mengacu pada ketidaktunggalan, tetapi pada dasarnya masingmasing tidak merepresentasikan hal yang sama. Konsep pluralitas mengandaikan adanya hal-hal yang lebih dari satu. Keragaman menunjukkan bahwa keberadaan yang lebih dari satu itu berbeda-beda heterogen, dan bahkan tak dapat disamakan. Sementara, multikulturalisme lebih menekankan pada kesediaan untuk menerima kelompok lain secara sama sebagai kesatuan, tanpa memperdulikan perbedaan budaya, etnik, jender, bahasa ataupun agama. Apabila pluralitas sekedar merepresentasikan adanya kemajemukan (yang lebih dari satu) multikulturalisme memberikan penegasan bahwa dengan segala perbedaannya itu mereka adalah sama di ruang publik.

Dalam hal ini, Bikku Parekh mengategorikan konsep multikulturalisme kedalam tiga bagian pokok. Pertama, perbedaan subkultur (subculture divesity), yaitu individu atau sekompok masyarakat yang hidup dengan cara pandang dan kebiasaan yang berbeda dengan komunitas besar dengan sistem nilai atau budaya pada umumnya yang berlaku. Kedua, perbedaan dalam perspektif (perspectival diversity) yaitu individu atau kelompok dengan perspektif kritis terhadap mainstream nilai atau budaya mapan yang dianut oleh mayoritas masyarakat di sekitarnya. Ketiga, perbedaan komunalitas (communal diversity), yakni individu atau kelompok yang hidup dengan gaya hidup yang genuine sesuai dengan identitas komunal mereka (indigeneous people way of life). ${ }^{13}$

\footnotetext{
12 Lihat Scott Lash dan Mike Feathersone (ed), Recognition And Difference: Politics, Identity Multiculture. London: Sage Publication, 2002, h.2-6. 13 Bhikhu Parekh, Rethingking Multiculturalism: Cultural Diversity and Political Theory (Cambridge: Harvard University Press, 2000, h.3-4.
} 


\section{c. Penelitian yang Relevan}

Telah cukup banyak penelitian yang dilakukan terhadap masyarakat Cina Benteng, antara lain sebagai berikut.

Pertama, penelitian Anita Sugianta, et al, "Analisa Perubahan Sosial Masyarakat Lebak Wangi (Perbandingan Era Reformasi dan Erde Baru)". Penelitian yang difokuskan pada masalah perubahan sosial pada masyarakat Lebak Wangi tersebut menghasilkan beberapa temuan berikut. Masyarakat Cina Benteng yang sudah bermukim di bantaran sungai Cisedani sejak 1830 dikenal sebagai masyarakat etnis Tionghoa dengan taraf kehidupan yang rendah, namun tetap setia dalam menjaga serta melestarikan adat istiadat dan tradisi leluhur bangsa Tionghoa, mereka sejak dulu sudah berakulturasi dengan penduduk setempat. Berbagai peristiwa politik, dampak perluasan pembangunan, majunya pendidikan dan teknologi serta kehidupan yang modern selama periode orde baru dan era reformasi telah membawa perubahan-perubahan terhadap kehidupan sosial ekonomi masyarakat Cina Benteng. Dalam penelitian ini ditemukan bahwa pada masyarakat Cina Benteng Sewan Lebak Wangi telah terjadi perubahan-perubahan sosial, walaupun perubahan yang terjadi telah membawa dampak terhadap kehidupan sosial ekonomi mereka, tetapi secara keseluruhan tidak merubah sistim sosial mereka.

Kedua, penelitian Hudaepah berjudul: "Perempuan Cina Benteng: Studi kasus perempuan Cina Benteng di Kampung Kandang Genteng, Desa Tanjung Burung Kecamatan Teluknaga, Kabupaten Tangerang, Propinsi Banten" (Universitas Gadjah Mada, Yogyakarta, 2008). Penelitian ini difokuskan pada keterlibatan perempuan-perempuan Cina Benteng yang hidupnya miskin dalam bekerja mencari nafkah, serta perjuangan mereka untuk ke luar dari kemiskinan. Tujuan penelitian ini adalah untuk mengetahui peran perempuan Cina Benteng di sektor domestik dan publik serta otonomi perempuan Cina Benteng dalam alokasi pendapatan keluarga. Selain itu mendeskripsikan etos kerja perempuan Cina Benteng dan nilai-nilai luhur apa saja yang dianut oleh perempuan Cina Benteng dalam menjalankan peranannya dalam keluarga dan masyarakat. Hasil penelitian ini menunjukkan bahwa untuk mempertahankan kehidupan keluarganya keterlibatan perempuan-perempuan Cina Benteng dalam mencari nafkah cukup besar.

Jika penelitian Anita Sugianta, et al. difokuskan pada masalah perubahan sosial pada masyarakat Cina Benteng dan penelitian Hudaepah difokuskan pada keterlibatan perempuan-perempuan Cina Benteng untuk keluar dari kemiskinan, maka penelitian ini memfokuskan pada perspektif historis dan sosiologis model kerukunan sosial pada masyarakat Cina Benteng.

\section{B. Metodologi Penelitian \\ 1. Metode Penelitian}

Untuk mengungkap model kerukunan soaial pada masyarakat multikultural Cina Benteng Tangerang dalam perspektif historis dan sosiologis, peneliti menggunakan metode penelitian deskriptif kualitatif karena metode ini merupakan upaya memahami berbagai konsep yang ditemukan dalam proses penelitian. Miller dan Crabtree (dalam Denzim dan Lincoln) menyatakan bahwa metode deskriptif kualitatif merupakan pilihan yang paling menguntungkan untuk membaca proses perubahan situasi sosial. ${ }^{14}$ Penelitian deskriptif kualitatif merupakan penelitian yang bersifat deskriptif dan cenderung menggunakan pendekatan induktif dalam melakukan kegiatan analisis. Teknik pengumpulan data terutama menekankan pada teknik studi kepustakaan, wawancara, observasi, dan dokumentasi. Penelitian deskriptif kualitatif berusaha menggambarkan suatu gejala sosial. Dengan demikian, penelitian ini bertujuan untuk menggambarkan sesuatu gejala atau suatu fenomena yang tengah berlangsung pada saat penelitian ini dilaksanakan.

\section{Teknik Pengumpulan Data}

Teknik pengumpulan data merupakan langkah yang paling strategis dalam penelitian, karena tujuan utama penelitian ini adalah mendapatkan data. Dalam penelitian deskriptif kualitatif data diperoleh dengan terjun secara langsung ke lapangan untuk melakukan studi

14 Norman K. Denzim dan Yvonna S. Lincoln, ed, Handbook of Qualitatif Research, Sage Publication, 1996, h. 207. 
kepustakaan, pengamatan (observasi), in-depth interview (wawancara mendalam), dan studi dokumentasi.

\section{a. Studi Kepustakaan}

Data-data kesejarahan digali melalui studi kepustakaan. Adapun langkah-langkah studi kepustakaan mencakup: (1) menyiapkan alat perlengkapan berupa pensil, pulpen dan kertas catatan, (2) menyusun bibliografi kerja, (3) mengatur waktu penelitian, dan (4) membaca dan membuat catatan penelitian.

\section{b. Observasi}

Observasi dilakukan untuk memperoleh data berupa gambaran yang ada di lapangan baik dalam bentuk sikap, tindakan, pembicaraan, interaksi interpersonal dan lain-lain. Untuk itu observasi dilaksanakan dalam bentuk pengamatan yang tidak berstruktur, dalam arti dilakukan dengan mengikuti alur situasi dan kondisi wilayah pengamatan, mengalir dan larut dalam aktivitas yang terjadi di lapangan.

Observasi penelitian ini diarahkan pada aspek-aspek sosio-kultural dalam kehidupan masyarakat masyarakat Cina Benteng, antara lain mencakup permukiman masyarakat Cina Benteng, aktivitas ekonomi, keagamaan, senibudaya, dan sebagainya. Observasi dilakukan secara langsung, baik verbal maupun non verbal, bahkan jika dipandang perlu dilakukan penelusuran lisan melalui wawancara.

Teknik pengumpulan data dengan cara ini sangat kompleks karena tidak hanya sekedar mengamati. Lebih jauh, pengamat menghendaki informasi yang lebih banyak dan kedudukan peneliti di sini bertujuan ingin mengetahui apakah tanpa kehadirannya para subyek akan berperilaku tetap atau menjadi berbeda. Pada teknik ini peneliti ikut serta dalam kegiatankegiatan yang dilakukan oleh subjek, seolaholah merupakan bagian dari mereka. ${ }^{15}$

Selanjutnya, pengamatan dilaksanakan dengan cara mengikuti kegiatan subyek penelitian yang paling memungkinkan untuk dilaksanakan pada masyarakat Cina Benteng Tangerang. Kehadiran peneliti untuk mengamati perilaku masyarakatnya yang khas. Pengamatan pada tahap ini difokuskan pada persoalan

15 Lexi Moleong, Metodologi Penelitian Kualitatif, Rosdakarya, Bandung, 2000, h.118. pokok yaitu mengidentifikasi model kerukunan sosial pada masyarakat Cina Benteng Tangerang dalam perspektif sosiologis.

\section{c. Wawancara}

Wawancara dilakukan untuk mendapatkan informasi yang tidak dapat diperoleh melalui observasi atau teknik pengumpulan data lainnya. Hal ini lebih disebabkan karena keterbatasan peneliti untuk melakukan pengamatan secara keseluruhan. Di samping itu, tidak semua data dapat diperoleh melalui pengamatan, sehingga mengharuskan peneliti untuk melakukan wawancara kepada responden yang dimaksudkan.

Untuk memperoleh informasi penting peneliti berusaha mencari nara sumber dari kalangan tokoh-tokoh terkemuka yang ada di tengah-tengah kehidupan masyarakat Cina Benteng. Narasumber yang dimaksud merupakan figur-figur yang memiliki pengetahuan dan sekaligus pemahaman terkait dengan sejarah keberadaan masyarakat Cina Benteng, berikut kondisi sosio-kultural yang berkembang dalam kehidupan masarakat Cina Benteng.

Data penelitian yang tidak diperoleh melalui observasi maupun wawancara ditelusuri lebih jauh melalui berbagai dokumen. Secara sederhana, dokumen dapat diklasifikasikan sebagai dokumen pribadi dan dokumen resmi. Dokumen pribadi adalah catatan atau karangan seseorang secara tertulis tentang tindakan, pengalaman, dan kepercayaannya. ${ }^{16}$ Dokumen resmi adalah dokumen milik institusi atau lembaga, baik berupa memo, pengumuman, majalah, bulletin, dan lain-lain).

\section{d. Dokumentasi}

Penggalian informasi melalui dokumendokumen penting seperti riwayat keberadaan masyarakat Cina Benteng, data-data pada kegiatan sosial di lingkungan masyarakat yang kompleks dan dinamis, dan sebagainya. Lewat metode ini pula, peneliti berharap akan dapat melihat data dari dimensi yang lainnya selain yang diperoleh dari pengamatan dan wawancara mendalam.

16 Lexy J. Moleong, Metodologi Penelitian Kualitatif: Edisi Revisi, Bandung: PT Remaja Rosdakarya, 2007. 


\section{Hasil Penelitian dan Pembahasan}

\section{Perspektif Historis Keberadaan} Masyarakat Multikultural Cina Benteng, Tangerang

Masyarakat Cina Benteng Tangerang saat ini merupakan generasi keenam atau ketujuh jika dihitung sejak awal kedatangannya di Indonesia. Profil dan karakteristiknya yang khas menjadikan mereka sebagai anti-stereotype dari etnis Cina di Indonesia pada umumnya. Sebut saja taraf ekonomi mereka yang ratarata masih berada di bawah standard. Seperti realitas di lapangan, mata pencaharian umum yang digeluti oleh masyarakat Cina Benteng tidak jauh beda dengan penduduk setempat. Meski ada beberapa yang relatif sukses sebagai pedagang, namun sebagian besar warga Cina Benteng masih hidup sederhana, bahkan tidak sedikit di antara mereka yang hidup di bawah garis kemiskinan. ${ }^{17}$

Keunikan masyarakat Cina Benteng terletak pada perpaduan antara keteguhan dan sekaligus kelenturan. Mereka merupakan masyarakat yang teguh memegang adat istiadat nenek moyang mereka yang sudah ratusan tahun. Hal ini terwujud dalam pelaksanaan upacara sekitar siklus kehidupan (perkawinan ciotao, kehamilan, dan kematian) dan upacara hari-hari besar agama (tahun baru Imlek, Cap Go Meh, Ceng Beng Peh Cun, dan lain sebagainya). Seperti halnya rumahrumah warga Tionghoa pada umumnya, di dalam rumah-rumah mereka masih didapati altar leluhur sebagai ciri utama kebudayaan Tionghoa. Pada sisi yang lain, masyarakat Cina Benteng merupakan masyarakat yang lentur. Hal ini ditunjukkan dengan proses amalgamasi, asimilasi, dan akulturasi dengan masyarakat dan sekaligus kebudayaan setempat.

Istilah "China Benteng" berasal dari kata "Benteng", sebuah nama yang bermula dari keberadaan sebuah benteng Belanda di kota Tangerang, yakni yang berada di pinggir sungai Cisedane. Benteng Belanda tersebut dibangun sebagai pos pengamanan guna mencegah serangan yang datang dari Kesultanan Banten. Dikaitkan dengan keberadaan Kesultanan Banteng, benteng tersebut merupakan benteng

17 Anita Sugianta, et al, Analisa Perubahan Sosial Masyarakat Sawan Lebak Wangi (Perbandingan Era Reformasi dan Orde Baru), Jakarta: Universitas Bina Nusantara, 2012. terdepan bagi pertahanan Belanda di pulau Jawa.

Menurut Widodo Adi, keberadaan masayarakat Cina Benteng terjadi setelah pemberontakan Cina di Batavia pada tahun 1740 di mana sebagian besar orang-orang Cina lari ke kawasan Tangerang dan sebagaian lagi ke Bekasi. Kawasan Kedaung, Kampung Melayu dan Teluk Naga di Tangerang menjadi kantungkantung pecinan baru. Pemberontakan terjadi untuk merespon keputusan Gubernur Jenderal Valkenier untuk menangkapi orang-orang Cina yang dicurigai. Mereka akan dikirim ke Srilanka untuk dipekerjakan di perkebunan-perkebunan milik VOC. Namun, pemberontakan tersebut segera dapat ditumpas dan bahkan perkampungan-perkampungan Cina di Batavia dihancurkan. Sedikitnya 10.000 orang tewas. Sejak saat itu orang-orang Cina mengungsi untuk mencari tempat baru di daerah Tangerang, seperti Mauk, Serpong, Cisoka, Legok, dan bahkan sampai Parung di daerah Bogor. ${ }^{18}$

Dalam hal ini Anita Sugianta, et al. berpendapat bahwa setelah tragedi Batavia pada tahun 1740 tersebut, banyak orang Tionghoa di Batavia yang kemudian pindah bermukim di daerah Tangerang dekat daerah bekas benteng Belanda. Peristiwa inilah yang kemudian menjadi awal dari penyebutan "Cina Benteng" bagi masyarakat keturunan Tionghoa yang tinggal di daerah tersebut. Mereka kemudian membaur dengan masyarakat setempat, bahkan tidak sedikit di antaranya yang memeluk agama Islam, menolak makan babi, serta menyatu dengan adat istiadat penduduk setempat. Menyangkut perpindahan agama tersebut memang terdapat beberapa penjelasan, antara lain adalah untuk menghindari pajak kepala yang khusus dikenakan kepada orang-orang Tionghoa pada saat itu dan agar diterima secara baik oleh penduduk setempat. Bahkan tidak sedikit di antara mereka yang melakukan amalgamasi, yakni dengan menikahi wanita setempat, sehingga memberikan kemungkinan yang lebih besar untuk terciptanya asimilasi dan aulturasi.

Pada masa kolonial, masyarakat Cina Benteng memberikan kontribusi yang besar terhadap kelangsungan kekuasaan kolonal

18 Lihat artikel Widodo Adi dengan judul "Gambang Kromong Teluk Naga". Harian Kompas, Selasa 1 Desember 2009. 
Belanda di Tangerang. Tidak sedikit masyarakat Cina Benteng yang diangkat menjadi kapitein Tionghoa dan mereka sangat loyal terhadap pemerintah kolonial Belanda. Saat kedatangan pasukan Jepang, mereka melakukan perlawanan secara habis-habisan meskipun pada akhirnya kalah.

Pada tahun 1946 terjadi kerusuhan etnis di Tangerang yang melibatkan antara masyarakat Cina dan penduduk pribumi. Saat itu penduduk pribumi menaruh kecurigaan terhadap masyarakat Cina terkait dengan keberpihakannya pada Belanda. Salah satu indikasinya adalah salah seorang tentara dari Cina Benteng yang pro-NICA, yakni Poh An Tuy, mengirim tentara dan mengungsikan masyarakat Cina Benteng yang selamat ke Batavia. Penduduk pribumi pendatang, terutama masyarakat Jawa dan Madura, beserta beberapa kelompok keagamaan dari masyarakat Sunda dan Betawi, melakukan peyerangan terhadap orang-orang Cina Benteng karena dianggap terlalu loyal terhadap NICA. ${ }^{19}$

Kerusuhan tersebut berhasil diredam oleh tentara gabungan NICA dan Poh An Tuy yang membela orang Cina Benteng. Orangorang Cina Benteng merasa sangat kehilangan ketika Belanda meninggalkan Tangerang pada tahun 50-an dan menyerahkan kota itu kepada Republik, karena mereka kehilangan pelindung mereka, maka terjadilah penyerangan dan perampasan terhadap orang-orang Cina Benteng. Tidak sedikit di antara orang-orang Cina Benteng yang sebelumnya kemudian berubah menjadi miskin karena harta leluhur mereka dirampas. Kehidupan orang-orang Cina Benteng terbilang sejahtera pada zaman kolonial Belanda.

Warga Cina Benteng sempat bersitegang dengan penduduk pribumi setelah Proklamasi Kemerdekaan. Pada 23 Juni 1946, rumah-rumah etnis Tionghoa di Tangerang menjadi sasaran kemarahan penduduk. Penduduk yang didukung oleh kaum Republik menjarah rumah-rumah warga Cina Benteng. Kemarahan penduduk pribumi dipicu oleh ulah seorang tentara NICA dari etnis Tionghoa yang menurunkan bendera Merah Putih dan menggantinya dengan bendera Belanda. Rosihan Anwar dalam harian Merdeka tanggal 13 Juni 1946 menulis bahwa pada saat itu hubungan warga Cina Benteng dan pribumi mengalami kemunduran paling ekstrem. Terlebih setelah Poh An Tuy, kelompok pemuda Cina Benteng pro-NICA, mengirim pasukan bersenjata dan mengungsikan masyarakat Cina Benteng yang selamat ke Batavia. Namun akhirnya kerusuhan pro-kemerdekaan itu berhasil diredam oleh koalisi antara tentara Poh An Thuy and tentara Kolonial Belanda.

Saat itu, semua etnis Cina Benteng nyaris terusir, dan ketika kembali, mereka tidak lagi mendapatkan tanah mereka dalam keadaan utuh. Tanah-tanah para tuan tanah diserobot pribumi. Tidak sedikit di antara mereka yang mendapati rumah-rumah yang mereka tinggalkan telah rata dengan tanah. ${ }^{20}$

Orang Cina Benteng dikenal dengan warna kulitnya yang sedikit lebih gelap (walaupun tetap berkulit kuning) dibandingkan warga keturunan Cina lainnya di Indonesia. Mereka lebih mirip dengan orang-orang Vietnam ketimbang orang Tiongkok. Kesenian mereka yang terkenal adalah kesenian campuran Betawi-Tionghoa, yakni Cokek. Cokek merupakan sebuah tarian berpasangan lelaki dan perempuan dengan iringan musik gambang kromong.

Agama yang dianut beragam antara lain Konghucu, Buddhisme, Taoisme, Katholik, Protestan, Pemujaan Leluhur, Pemujaan Surga, dan ada sedikit yang beragama Islam.

Meskipun masyarakat Cina Benteng sudah tidak berbahasa Cina, namun yang menarik mereka tetap melestarikan budaya leluhur dan tradisi Tiongkok. Hal ini dapat dilihat dari tradisi pernikahan mereka yang menggunakan upacara pernikahan gaya Dinasti Manchu (Qing). Mereka juga mengenakan pakaian gaya Dinasti Manchu seperti Manchu Robe dan Manchu Hat pada saat menikah. Orang Cina Benteng adalah satu-satunya komunitas Tionghoa di Indonesia yang memiliki darah orang Manchu. Tidak heran jika hanya orang Cina Benteng yang masih tetap menggunakan upacara nikah gaya Dinasti Manchu setelah Dinasti Qing runtuh pada tahun 1912. ${ }^{21}$

Dengan demikian, model kerukunan sosial pada masyarakat multikultural Cina Benteng Tangerang terbentuk secara historis sejak 
kedatangan mereka di daerah aliran sungai Cisedane. Proses historis telah menjadikan masyarakat Cina Benteng yang memiliki perpaduan yang unik, yakni keteguhan mereka dalam memegang adat istiadat nenek moyang mereka yang sudah ratusan tahun, serta kelenturan mereka sehingga memungkinkan mereka untuk melakukan proses amalgamasi, asimilasi, dan akulturasi dengan masyarakat dan sekaligus kebudayaan setempat.

\section{Perspektif Sosiologis Model Kerukunan Sosial pada Masyarakat Multikultural Cina Benteng Tangerang}

Dilihat dari ciri fisiologis masyarakat Cina Benteng tampak berkulit hitam dan nyaris tidak tampak kecinaannya, kecuali pada unsur-unsur religi dan budayanya yang masih mempertahankan tradisi nenek moyang mereka namun berakulturasi dengan corak lokal. Bisa dikatakan bahwa masyarakat Cina Benteng telah mengalami pribumisasi dengan berbaur seperti generasi pendahulunya.

Seperti yang diuraikan pada bagian sebelumnya, bahwa setelah tragedi Batavia pada tahun 1740, banyak orang Tionghoa di Batavia yang kemudian pindah bermukim di daerah Tangerang dekat daerah bekas benteng Belanda. Mereka ingin diterima dengan baik oleh warga setempat dalam rangka memperoleh kepastian untuk melangsungkan kehidupan secara normal. Itulah sebabnya mereka berusaha membaur dengan masyarakat setempat. Untuk mendukung proses pembauran tersebut mereka melakukan beberapa langkah, antara lain: (1) memeluk agama Islam dan berusaha untuk melaksanakan ajarannya, di antaranya adalah dengan tidak memakan daging babi, (2) melaksanakan budaya, adat istiadat, dan tradisi yang terdapat pada masyarakat setempat, serta (3) melakukan amalgamasi, yakni dengan menikahi wanita setempat. Diduga, amalgamasi inilah yang menjelaskan mengapa ciri-ciri fisik masyarakat Cina Benteng lebih mirip sebagai penduduk pribumi dibandingkan dengan peranakan Cina pada umumnya. Ong Gian (47), misalnya. Peranakan Cina Benteng ini kulitnya cenderung gelap seperti pribumi, sementara matanya tidak sipit sebagaimana peranakan Cina pada umumnya. Dalam hal ciri fisik, Ong Gian adalah representasi masyarakat Cina Benteng pada umumnya. Tidak heran jika masyarakat Cina Benteng diidentifikasi sebagai stereotip orang Cina berkulit gelap, jagoan bela diri, dengan kehidupan yang serba atau malah miskin.

Wilayah Cina Benteng merupakan wilayah yang memiliki beberapa keunikan. Tentu saja keunikan tersebut ditopang oleh kondisi masyarakat pendukungnya yang bersifat multikultural. Secara umum tampak rumahrumah dan pola permukiman yang khas Cina, lengkap dengan Wihara Maha Bodhi (Tjong Tek Bio) yang konon sudah berdiri sejak tahun 1837 Masehi.

Kondisi sosial masyarakat Cina Benteng boleh disebut sebagai salah satu model kerukunan sosial yang ada di negeri ini. Di tengah-tengah kehidupan masyarakat Cina Benteng terdapat beberapa rumah ibadah yang mencerminkan adanya umat dari beberapa agama yang berbeda. Sebut saja kelenteng sebagai rumah ibadah bagi penganut Khonghuncu, masjid sebagai rumah ibadah bagi penganut Islam lengkap dengan taman pendidikan al-Qur'an, serta gereja sebagai rumah ibadah penganut Kristen. Letak ketiga rumah beribadah yang saling berdekatan menunjukkan bahwa masyarakat Cina Benteng memiliki toleransi beragama yang sangat tinggi. Uniknya, sebagai peranakan Tionghoa, secara umum masyarakat Cina Benteng mengakui sebagai orang Betawi.

Perlu dicatat bahwa sepanjang sejarah masyarakat Cina Benteng tidak pernah terjadi konflik yang disebabkan oleh faktor perbedaan agama dan keyakinan. Dengan demikian, kerukunan sosial pada masyarakat Cina Benteng, terutama kerukunan antarumat beragama, merupakan sebuah realitas sosial yang belum terbantahkan. Justru yang terjadi adalah adanya proses asimilasi dan akulturasi, sehingga terbentuklah masyarakat Cina Benteng yang sama sekali berbeda dengan masyarakat Cina di negeri leluhurnya. Salah satu buktinya adalah terlalu sedikitnya warga Cina Benteng yang dapat berbahasa Cina karena telah terbiasa dengan penggunaan bahasa Indonesia atau bahasa Betawi sebagai bahasa komunikasi dalam kehidupan sehari-hari. Kendatipun demikian, mayoritas warga Cina Benteng tetap 
mempertahankan agama leluhur mereka, yakni Khonghucu dan Budha.

Produk budaya peranakan Tionghoa tidak lepas dari segi kehidupan masyarakat Indonesia. Budaya ini merambah masuk ke dalam segala hal seperti ritual pernikahan, kuliner, tari-tarian, musik, dan lain-lain. Perkembangan budaya pada masyarakat Cina Benteng menjadi bagian hidup yang menarik untuk ditelusuri sebagai salah satu aset budaya bangsa Indonesia.

Asimilasi dan akulturasi pada masayarakat Cina Benteng tidak hanya terjadi dalam lapangan keseniannya, melainkan juga terjadi pada tradisi perkawinan, sistem religi dan kepercayaan, termasuk dalam penggunaan bahasa. Bahasa di sini menjadi penting karena berfungsi sebagai transmitter komunikasi sehingga lambat laun menjadi faktor determinan dalam membentuk sebuah pola pergaulan. Secara teori, proses asimilasi dan akulturasi hanya terjadi melalui interaksi damai dalam waktu yang lama. Faktanya, pada masyarakat Cina Benteng terdapat beberapa produk budaya sebagai hasil asimilasi dan akulturasi. Produkproduk asimilasi dan akulturasi tersebut dapat diperhatikan dalam Tabel 1 berikut ini.

Tabel 1

Produk asimilasi dan akulturasi pada masyarakat Cina Benteng

\begin{tabular}{|c|c|c|}
\hline No. & $\begin{array}{c}\text { Produk } \\
\text { asimilasi dan } \\
\text { akulturasi }\end{array}$ & Keterangan \\
\hline 1. & $\begin{array}{l}\text { Pola } \\
\text { permukiman }\end{array}$ & $\begin{array}{l}\text { Seperti penjelasan David Kwa, peranakan Tionghoa, kaum Tionghoa, untuk } \\
\text { selanjutnya disebut dengan Cina Benteng, banyak yang tinggal di luar Pecinan, } \\
\text { tepatnya di daerah pedesaan di sekitar daerah aliran sungai Cisedane yang } \\
\text { sekarang dikenal dengan istilah Pasar Lama dan Pasar Baru. Intensitas hubungan } \\
\text { sosial antara masyarakat Cina Benteng dengan masyarakat Betawi lambat laun } \\
\text { menciptakan kemungkinan bagi terjadinya proses asimilasi dan akulturasi } \\
\text { kebudayaan, yakni budaya Tionghoa dengan budaya Betawi. Proses asimilasi dan } \\
\text { akulturasi itulah yang, menurut David Kwa, telah menjadikan masyarakat Cina } \\
\text { Benteng tidak identik dengan kebudayaan Cina asli. Masyarakat Cina Benteng tidak } \\
\text { merayakan Tahun Baru Imlek seperti yang dilakukan oleh orang Cina. Misalnya, } \\
\text { dalam perayaan Tahun Baru Imlek masyarakat Cina Benteng melengkapi hidangan } \\
\text { dengan menyuguhkan nastar dan/atau lepet yang diadopsi dari tradisi Betawi. }\end{array}$ \\
\hline 2 & $\begin{array}{l}\text { Bahasa } \\
\text { komunikasi }\end{array}$ & $\begin{array}{l}\text { Dalam percakapan sehari-hari, masyarakat Cina Benteng tidak menggunakan } \\
\text { bahasa Cina, bahkan tidak bisa berbahasa Cina. Bahasa komunikasi, berikut } \\
\text { logatnya, tak ubahnya masyarakat Tangerang pada umummnya, yakni bahasa dan } \\
\text { logat Sunda pinggiran bercampur Betawi. Jauh berbeda dengan masyarakat Cina } \\
\text { lainnya, misalnya masyarakat Cina Singkawang, Kalimantan Barat, yang masih } \\
\text { menggunakan bahasa Cina dalam kehidupan sehari-hari. }\end{array}$ \\
\hline 3. & $\begin{array}{l}\text { Prosesi } \\
\text { pernikahan } \\
\text { tradisional }\end{array}$ & $\begin{array}{l}\text { Masyarakat Cina Benteng juga mengadopsi beberapa tradisi lokaldalam kaitannya } \\
\text { dengan upacara pernikahan. Selain menjunjung tinggi budaya Cina, mereka } \\
\text { juga mengadopsi beberapa unsur budaya lokal lainnya. Misalnya, dalam busana } \\
\text { pengantin terdapat unsur Cina, Arab, dan India yang berkombinasi menjadi } \\
\text { suatu detail yang mewah sebagaimana aksesoris pengantin dalam adat Betawi. } \\
\text { Sentuhan ornamen etnik Cina tampak pada motif bunga, naga emas, dan burung } \\
\text { hong yang bisa dilihat pada perlengkapan busana serta aksesoris kepala pengantin } \\
\text { wanita. Sementara, terkait dengan prosesi upacara pernikahan tradisional yang } \\
\text { disebut dengan Chio Tau, dilaksanakan dengan berbagai ritual dan busana khas } \\
\text { ala peranakan Tionghoa yang disebut dengan busana Hwa Kun. Dalam upacara } \\
\text { Chio Tau juga terdapat tradisi makan nasi melek dan ritual makan onde-onde yang } \\
\text { diakhiri dengan tehpai atau tuang teh. Ini adalah bentuk refleksi dari kemajemukan } \\
\text { Tionghoa yang dilengkapi dengan kekhasan budaya Betawi. }\end{array}$ \\
\hline
\end{tabular}




\begin{tabular}{|c|c|c|}
\hline 4. & Pakaian adat & $\begin{array}{l}\text { Pakaian adat masyarakat Cina Benteng merupakan perpaduan antara pakaian adat } \\
\text { Tionghoa (suku Hokian) dan pakaian adat Betawi. Pakaian adat kaum lelaki berupa } \\
\text { baju koko hitam, celana panjang, dengan topi yang khas yang mirip dengan caping. } \\
\text { Sedangkan pakaian adat wanita yang disebut hwa-kun, berupa blus dan bawahan } \\
\text { lengkap dengan hiasan kepala serta tirai penutup wajah. Selain itu, wanita Cina } \\
\text { Benteng juga mengenakan kebaya encim dengan aksen kembang goyang sebagai } \\
\text { hiasan kepala. Ini menunjukkan pengaruh Betawi dalam pakaian tersebut. }\end{array}$ \\
\hline 5. & $\begin{array}{l}\text { Musik } \\
\text { Gambang } \\
\text { Kromong }\end{array}$ & $\begin{array}{l}\text { Bentuk akulturasi dari budaya Cina dan budaya Betawi juga terlihat pada kesenian } \\
\text { Lenong yang dimeriahkan oleh orkes pengiring Gambang Kromong. Sebagai } \\
\text { orkes pengiring, Gambang Kromong dilengkapi dengan beberapa instrumen } \\
\text { musik yang merupakan perpaduan antara alat-alat kesenian Cina dan alat-alat } \\
\text { kesenian lokal. Unsur alat-alat musik Cina terlihat pada musik gesek Cina, yakni } \\
\text { kongahyan, tehyan, dan skong. Unsur alat-alat musik setempat dapat terlihat pada } \\
\text { kecrek, gendang, kempul dan gong. Sementara, terkait dengan Lagu-lagu yang } \\
\text { biasa dibawakan dalam orkes tersebut, selain perpaduan antara lagu-lagu lokal } \\
\text { seperti kicir-kicir, ondel-ondel, jali-jali, dan lagu-lagu Cina pobin mano Kongjilok, } \\
\text { Bankinhwa, Posilitan, dan Caicusiu meskipun pada umumnya hanya disajikan secara } \\
\text { instrumental. Menurut Widodo Adi, Gambang Kromong tercipta ketika orang- } \\
\text { orang Tionghoa peranakan di waktu senggangnya memainkan lagu-lagu Tionghoa } \\
\text { dengan instrumen gesek asal negeri leluhur mereka berupa su-kong, the-bian, dan } \\
\text { kong-a-hian yang dipadu dengan bangsing (suling), kecrek, ningning, dan gambang yang } \\
\text { asli Betawi. Pada tahun } 1880 \text {-an ditambah lagi dengan kromong, kendang, kempul, } \\
\text { dan gong. Dari sinilah istilah Gambang Kromong berasal.1 }\end{array}$ \\
\hline 6. & Tari Cokek & $\begin{array}{l}\text { Tari Cokek dianggap sebagai tari unggulan yang dipentaskan pada pesta-pesta } \\
\text { hiburan, mulai dari pesta sunatan hingga pesta perkawinan. Pada awalnya Tari } \\
\text { Cokek dibina dan dimiliki oleh kelompok elit, yakni cukong-cukong peranakan } \\
\text { Cina yang kaya raya. Pada dasarnya Tari Cokek tidak dapat dipisahkan dari musik } \\
\text { Gambang Kromong. Dalam Gambang Kromong dikenal perkembangan lagu- } \\
\text { lagu, mulai dari instrumentalia yang berasal dari lagu tradisional Tionghoa yang } \\
\text { berasal propinsi Hokian Cina Selatan, hingga lagu dalem yang dinyanyikan dalam } \\
\text { bentuk pantun berbahasa Betawi yang dibawakan oleh Wayang Cokek. Istilah } \\
\text { cokek berasal dari kata chioun-khek, yang berarti menyanyi dalam bahasa Hokian). } \\
\text { Dalam perkembangan selanjutnya muncul lagu sayur yang diciptakan untuk } \\
\text { ngibing (menari) sehingga menambah peran dari wayang cokek yang tidak sekedar } \\
\text { menyanyi melainkan juga merangkap menjadi penari untuk menemani ngibing } \\
\text { bersama tamu. Ngibing itu sendiri mengindikasikan semakin kuatnya pengaruh } \\
\text { budaya Melayu, Sunda, dan Jawa, di samping tradisi budaya Tionghoa itu sendiri. } \\
\text { Dengan demikian, Gambang Kromong dan/atau Tari Cokek mengindikasikan } \\
\text { sebagai kesenian yang berperan sebagai media komunuikasi antarbudaya. }\end{array}$ \\
\hline
\end{tabular}

Adanya beberapa bukti dari proses asimilasi dan akulturasi seperti di atas menunjukkan adanya kerukunan sosial, bahwa masyarakat Cina Benteng dapat hidup bersama dan bahkan menyatu dengan masyarakat Betawi. Proses asimilasi dan akulturasi tersebut, selain melahirkan suatu masyarakat yang unik, juga sekaligus memperkaya keanekaragaman budaya di Indonesia.

\section{Kesimpulan}

Terdapat dua kesimpulan penting yang dapat dirumuskan dari hasil penelitian ini, yakni sebagai berikut.

Pertama, model kerukunan sosial pada masyarakat multikultural Cina Benteng Tangerang terbentuk secara historis sejak kedatangan mereka di daerah aliran sungai Cisadane. Proses historis telah menjadikan masyarakat Cina Benteng yang memiliki 
perpaduan yang unik, yakni keteguhan mereka dalam memegang adat istiadat nenek moyang mereka yang sudah ratusan tahun, serta kelenturan mereka sehingga memungkinkan mereka untuk melakukan proses amalgamasi, asimilasi, dan akulturasi dengan masyarakat dan sekaligus kebudayaan setempat. Poin penting yang perlu digarisbawahi dari kelenturan masyarakat Cina Benteng antara lain: (1) adanya usaha memeluk agama Islam dan berusaha untuk melaksanakan ajarannya kendatipun masih dalam level terbatas, (2) adanya usaha untuk melaksanakan budaya, adat istiadat, dan tradisi yang terdapat pada masyarakat setempat, serta (3) melakukan amalgamasi, yakni dengan menikahi wanita setempat.

Kedua, dalam perspektif sosiologis, model kerukunan sosial pada masyarakat Cina Benteng semakin terbentuk memalui proses amalgamasi sehingga memberikan kemungkinan yang lebih terbuka bari proses asimilasi dan akulturasi dalam jangka waktu yang panjang. Secara teori, proses asimilasi dan akulturasi hanya terjadi melalui interaksi damai dalam waktu yang lama. Adapun produk asimilasi dan akulturasi setidaknya dapat diperhatikan dalam hal pola permukiman, bahasa komunikasi, prosesi pernikahan tradisional, pakaian adat, musik gambang kromong, dan tari cokek.

\section{Daftar Pustaka}

Parekh, B. Rethingking Multiculturalism: Cultural Diversity and Political Theory. Cambridge: Harvard University Press. 2000.

Denzim, N.K. dan Yvonna S.L. ed. Handbook of Qualitatif Research. Sage Publication. 1996.

Kamanto, S. "Multicultural Education in Schools: Challenges in Its Implementation" Jurnal Antropologi Indonesia in Collaboration with TIFA Foundation, Departement of Antropology, Faculty of Social and Political Sciences, Univercity of Indonesia. 2004.

Suryadinata, L. Penduduk Indonesia, Etnis dan
Agama dalam Era Perubahan Politik. Jakarta: LP3ES. 2000.

Chinese Indonesians, State Policy, Monoculture and Multiculture. Easten University Press. 2000.

Lash, S. and Feathersone, M. (ed). Recognition And Difference: Politics, Identity Multiculture.

London:Sage Publication. 2002.

Watson, CW. Multiculturalism Concepts in the Social Studies. Open University Press. 2000.

Adi, W.'Gambang Kromong Teluk Naga". Harian Kompas, Selasa 1 Desember 2009.

Suparlan, P. Menuju Masyarakat Indonesia Yang Multikultural, Makalah, Disajikan pada Simposium Internasional Jurnal Antropologi Indonesia ke-3, Membangun Kembali "Indonesia yang Bhinneka Tunggal Ika", Menuju Masyarakat Multikultural, Universitas Udayana, Denpasar, Bali, 1619 Juli 2002

Karim, A.G. Multikulturalisme. Yogyakarta: Bahan Ajar Program Pascasarjana Universitas Gajah Mada. 2010.

Haris, S. Paradigma Baru Otonomi Daerah. Jakarta: Pusat Penelitian Politik Lembaga Ilmu Pengetahuan Indonesia (P2P LIPI). 2001.

Snelbecker, G. 1984. Learning Theory Instructional Theory, and Psycho-educational Design. USA: McGrau-Hill, Inc.

Suriasumantri, J.S. Berfikir Sistem:Konsep, Penerapan Teknologi dan Strategi Implementasi. Jakarta: FPS IKIP Jakarta. 1996.

Sugianta, A. et al. Analisa Perubahan Sosial Masyarakat Sawan Lebak Wangi (Perbandingan Era Reformasi dan Orde Baru). Jakarta: Universitas Bina Nusantara. 2012.

Raco, J.R. Metode Penelitian Kualitatif: Jenis, Karakteristik dan Keunggulannya. Jakarta: Grasindo. 2010.

Moleong, L.J. Metodologi Penelitian Kualitatif: Edisi Revisi. Bandung: PT Remaja Rosdakarya. 2007.

Nazir, M. Metode Penelitian. Jakarta: Ghalia Indonesia. 2003. 